Schanz.-Deutsch. Optische Wochenschr.. Nr. 297, 1917.

Idem.-Münchener med. Wochenschr.. Nr. 19, 29, 30, 1915 ; $\mathrm{Nr} 68, \mathrm{~S} .19,1921$

Idem.-Bioch. Zeitschr., Bd. 71, S. 406, 1915.

Idem.-Arch. f. Ophthal., Bd. 86, S. 549 and 568, 1913 ; Bd. 88, S. 437, 1915 ; Bd. 89, S. 556, 1916 ; Bd. 91, S. 238, 1916 ; Bd. 96, S. 172, 1918 ; Bd. 106, S. 171,1921 ; Bd. 107, S. 190, 1922.

Schanz und Stockhausen.-Arch. f. Ophthal., Bd. 65, S. 49 and 152, 1908 ; Bd. 73, S. 184 and 553, 1909.

Schulek.-Ungar. Beitr. z. Augenheilk., Bd. 1, S. 106, 1895.

Setschenow.-Arch. f. Ophthal., Bd. 5, S. 205, 1859.

Soret.-Comptes Rendus, Vol. XCVII, pp. 314, 572, 642, 1883.

von Szily.-Klin. Monatsbl. f. Augenheilk., Bd. 49, S. 150, 1911 ; Bd. 51, S. 164,1913 .

von Szily und Arisawa.-Berichte d. Ophthal. Gesellsch., Heidelberg, S. 253, 1912.

Thunberg.-Ergeb. d. Physiol., Bd. 11, S. 328, 1911.

Idem.-Skand. Arch. f. Physiol., Bd. 35, S. 163, 1918 ; Bd. 40, S. 1, 1920.

Tiffany-Indian med. Gaz., Vol. XLIX, p. 326, 1914.

Toufesco.-Annal. d'Ocul., T. 136, p. 1, 1906.

Uhlenhuth.-Deutsch. med. Wochenschr., 1906.

Uhlenhuth und Händel.-Zeitschr. f. Immunitätsforschung, Bd. 4, H. 6, 1910.

Valentin.-Zeitschr.f. Physiol. Chemie, Bd. 105, S. 33, 1919.

Wick.-Arch.f. Ophthal, Bd. 109, S. 224, 1922.

Widmark. - Skand. Arch.f. Physiol., Bd. 1, S. 264, 1889 ; Bd. 4, S. 288, 1892.

Wieland.-Berl. f. d. chem. Gesellsch., Bd. 45, 46, 47, and 54, 1921.

Idem.-Ergebn. d. Physiol., Bd. 20, S. 481, 1922.

Yoshiharu. -Mit. a. d. med. fak. d. kais. Univ., Bd. 29, H. 1, 1922.

Young.-Proc. Roy. Soc. B, Vol. XCIV, p. 235, 1922.

\title{
HAEMATOMA OF THE CORNEA. A CLINICAL NOTE \\ BY
}

\author{
Glomge Young and Arthur W. D'Ombrain
}

COLCHESTER

WhILE preparing to perform a double sclerectomy on a female patient, aged 72 years, we observed a strange phenomenon which neither of us had ever seen before. The patient had absolute glaucoma in the right eye and a far advanced glaucoma in the left, the tension being nearly 90 and over 90 Schiötz in the two eyes respectively. We saw on the cornea of the right eye (absolute glaucoma) a couple of streaks of blood, about $1.5 \mathrm{~mm}$. long, just below the upper part of the limbus. They seemed to be on the surface, but would neither flush nor brush away and did not stain the swab. As we watched, new streaks appeared on either side, spreading laterally further and further, and finally appearing as small bleb-like haematomata, protruding above the corneal level and occupying about $2 / 5$ ths of the circumference of the cornea. They exactly corresponded to the position of the most intense 
part of an arcus senilis, with exactly the same sharp line of demarcation at the limbal edge and the same clear zone of cornea. A series of blebs thus formed, growing more and more prominent, till they became confluent and formed a band-like strip, broadening to about $2 \mathrm{~mm}$. The whole process only occupied a period of about two or three minutes, when the bubbles burst and discharged a small quantity of liquid blood. Two days later there was no trace left. Probably an extravasation of blood took place just beyond the limbal vessels and wedged its way beneath the corneal epithelium, and, after elevating this off Bowman's membrane, finally burst it. The situation of this haematoma was interesting, as well as the clear zone of cornea, and doubtless has its anatomical reasons. But in spite of the similarity of position we do not think that there can be any true analogy between the anatomical causes of this appearance and those of arcus senilis. Arcus senilis is a degeneration, probably of a modified fat, occurring at the peripheral edge of Bowman's membrane, which does not quite reach the limbus (Collins and Mayou). It is likely that the haematoma here described formed just where the limbal circulation leaves its conjunctival support and pours its lymph into the cornea. The tissues and vessels being in a degenerate and friable condition in these regions in absolute glaucoma, they broke along the zone where they lose their conjunctival support, in a sharply defined line. We offer this as a partial explanation of what occurred.

\section{ANNOTATION}

\section{Ophthalmology in Fiction}

It must be conceded that the whole tone of the doctor in fiction has been immeasurably raised during the last century. Smollett, himself a medical man, draws, in Roderick Random, vile pictures of the general practitioners of his day, Messrs. Crabb and Potion, compounds of the charlatan and the buffoon; while his only educated physician that occurs to us is the one whom Perigrine Pickle met in Paris, who is usually regarded as a caricature of Dr. Akenside. How great a part the medical profession plays in fiction will be recognized by all who have thought about the matter; but ophthalmology and the oculist, being of comparatively recent development, do not find much place in English literature before the middle of the last century. Lytton, in Night and Morning, tells us of an interesting case of family strabismus, where Beaufort, 